\title{
Electric Resistance Welding of Austenitic and Galvanized Steel Sheets
}

\author{
Ivo HLAVATÝ, Petra HÁJKOVÁ, Lucie KREJČí, Robert ČEP
}

\begin{abstract}
Nowadays the automotive industry is predominantly using heterogeneous welded joints. The welding of an austenitic and galvanized steel sheet is one of the most common applications, which are using resistive spot welding (RSW); it is a process in which contacting metal surfaces are joined by the heat obtained from resistance to an electric current. The electrodes used influence the quality of a heterogeneous welded joint. This paper describes the influence of the electrodes used, their material and shapes, and the final heterogeneous welded joint, which consists of two or three sheets. They will be compared with each other two electrode materials: CuCr1Zr original (material used for both electrodes) of new material $\mathrm{CuCr} 1 \mathrm{Zr}$ (upper electrode replacement) and $\mathrm{CuCo} 2 \mathrm{Be}$ (removable bottom electrode). Furthermore, the improved electrode geometry where the original planar electrode is passed to the electrode with radius surface, due to poor access to the point of welding. The aim of this research was to achieve a better quality of spot welded joints consisting of two or three sheets.
\end{abstract}

Keywords: austenitic steel; electric resistance welding method; ERW; galvanized steel; sheet; welding

\section{INTRODUCTION}

Sheets with a protective layer are very frequently used materials. These materials are mainly used in the automotive industries and for white goods. The protective zinc layer creates corrosion protection on the steel surface. The protective zinc layer could be welded by the electric resistance welding (ERW) method using the same methods as for sheets without surface protection. However, we cannot use the same welding parameters as a welding material without surface protection. The protective zinc layer has the main impact on the welding process and the quality of welded joints. The chemical composition of the zinc layer, its structure and thickness, have a major influence on the electric resistance welding process $[1,3]$.

Austenitic steel is used for heterogeneous welded joints where high corrosion resistance is strictly required. Problems with the implementation of heterogeneous welded joints may be created by the chemical composition or the structure itself. The final welded joints must show satisfactory results with regard to the safety and lifetime period of the complete welded structure [2].

This study describes the results obtained from the input process (original geometry and electrode material). The following evaluation of the results was achieved through images macrostructure and microhardness values. From obtained conclusions were proposed amendments that tested the same as at the entrance to allow the conclusion of this study to make an overall assessment of the analysis of two and three sheets.

\section{CONDITIONS OF EXPERIMENT}

The different chemical compositions of the austenitic or galvanized steel sheets can be seen on metallographic structures [8]. The welding of heterogeneous welded joints by resistance spot welding, creates many problems, which have an effect on the final quality of the welded joints [6]. Zinc creates adhesion and diffusion on the electrode surface at the contact zone. This increases resistance between the electrodes and sheets. The ratio in resistance change leads to a reduction of electric resistance between the metal sheets at the connection point and this could create substandard welded joints [10]. Adhesion and zinc diffusion create an overheating of electrodes and this leads to a shortened lifetime. The lifetime period is approximately two hours for the resistance spot welding of heterogeneous welded joints [9]. Chemical composition of steels is shown in Tab. 1.

Table 1 Chemical composition - galvanized steel and austenitic material [2, 3]

\begin{tabular}{|c|c|c|}
\hline \multirow{2}{*}{$\begin{array}{c}\text { Composition } \\
\text { (wt. \%) }\end{array}$} & 1.0355 & 1.4301 \\
\cline { 2 - 3 } & 0,12 & $\leq 0,07$ \\
\hline $\mathrm{C}$ & 0,5 & - \\
\hline $\mathrm{Si}$ & 0,6 & - \\
\hline $\mathrm{Mn}$ & 0,1 & - \\
\hline $\mathrm{P}$ & 0,045 & - \\
\hline $\mathrm{S}$ & 0,3 & $17,0 \div 19,5$ \\
\hline $\mathrm{Ti}$ & - & $8,0 \div 10,5$ \\
\hline $\mathrm{Cr}$ & - & \\
\hline $\mathrm{Ni}$ & &
\end{tabular}

Welded joints can be divided into two types (see Fig. 1): a spot welded joint of two sheets (galvanized and austenitic) and a spot welded joint of three sheets $(1 \times$ galvanized and $2 \times$ austenitic) with a thickness of $2 \times 0.4$ $\mathrm{mm}$ and in two cases $1 \times 0.4 \mathrm{~mm}$ [7].

Tab. 2 shows the marking of galvanized steel sheets, and the thickness and types of coatings.

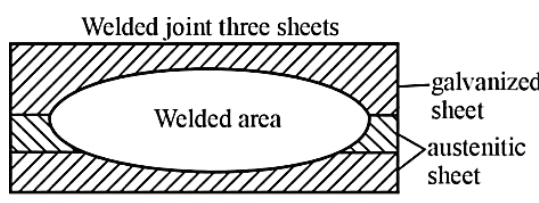

Welded joint two sheets

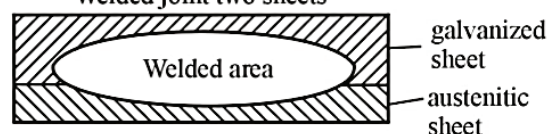

Figure 1 Types of welded joints

Table 2 Characteristics of a galvanized steel sheet [3]

\begin{tabular}{|c|c|c|}
\hline Material marking & Sheet thickness & Type of coating \\
\hline 1,0355 & $0,8 \mathrm{~mm}$ & $\mathrm{Z} 100$ \\
\hline
\end{tabular}

\section{EXPERIMENTAL PART}

An experiment was performed on a workpiece which was welded using Conntronic equipment. The material 
$\mathrm{CuCr} 1 \mathrm{Zr}$ was used for the upper and lower electrode. Table 3 shows the chemical composition of the electrodes used. We can see complex geometry of welded part with designating of electrode tracks and Fig. 3 shows the shape of used electrodes.

Table 3 Chemical composition - electrode materials [4]

\begin{tabular}{|c|c|c|}
\hline \multirow{2}{*}{ Material marking } & Abbreviation & $\mathrm{CuCr} 1 \mathrm{Zr}$ \\
\cline { 2 - 3 } & Number & $\mathrm{CW} 106 \mathrm{C}$ \\
\hline \multirow{3}{*}{ Chemical composition / \% } & $\mathrm{Cu}$ & residual \\
\cline { 2 - 3 } & $\mathrm{Cr}$ & $0,5 \div 1,2$ \\
\cline { 2 - 3 } & $\mathrm{Fe}$ & 0,08 \\
\cline { 2 - 3 } & $\mathrm{Si}$ & 0,1 \\
\cline { 2 - 3 } & $\mathrm{Zr}$ & $0,03 \div 0,3$ \\
\hline Density g/cm3 & $\mathrm{MS} / \mathrm{m}$ & 46 \\
\hline \multirow{2}{*}{ Electrical conductivity } & $\% \mathrm{IACS}$ & 79 \\
\cline { 2 - 3 } & \multicolumn{2}{|c|}{} \\
\cline { 2 - 3 } & \multicolumn{2}{|c|}{8,9} \\
\hline
\end{tabular}
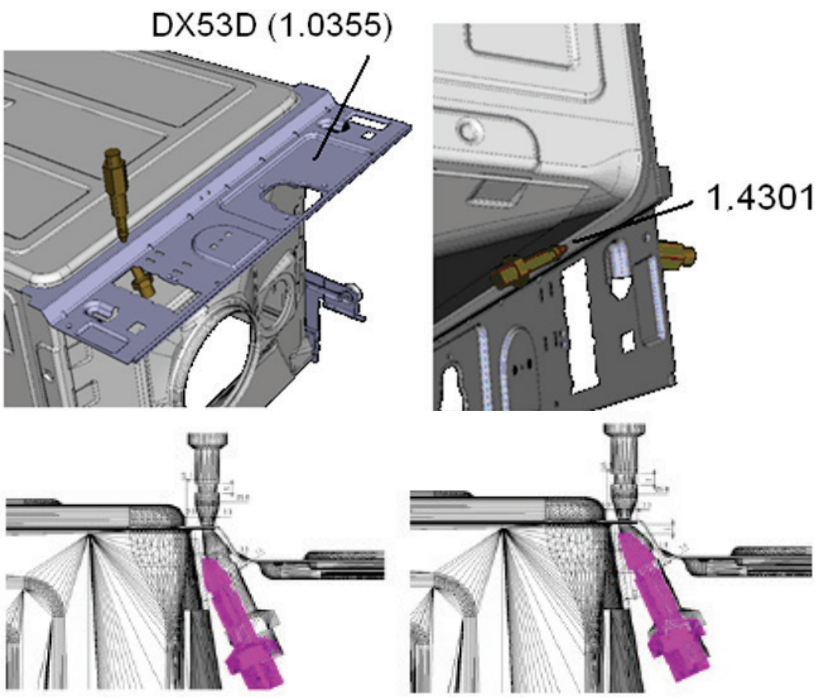

Figure 2 Electrode position at weldment
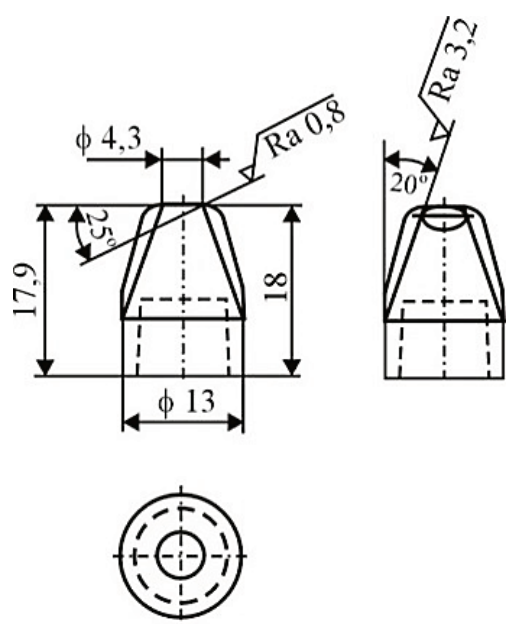

Figure 3 The shape of the upper and lower electrodes used for welding

Fig. 5 shows the macrostructure of a weld joint for two and three sheets. The unsuitable size and shape of the welding lens is evident for both variants. Simultaneously, we can observe the parallelism of sheets at the welding lens, which is caused by improper welding electrode geometry, along with poor access to future welding point. Poor access to the area of the weld, especially in the lower electrode can be seen in Fig. 2. The reducing of the welding lens's size is created by changes in the resistance ratio in a welded joint after the repeated implementation of a spot welded joint. Another monitored parameter was the measurement of the micro hardness of the welded joints for two and three sheets see Fig. 4. For a welded joint with three plates we can see a large increasing in hardness (from $200 \div 260$ HV0.05 to $420 \div 450$ HV0.05). Microhardness was measured perpendicularly from the center of the lens welded galvanized sheet over the lens to weld austenitic steel. Microcracks, with a large step accumulation in microhardness, are observed for these welded joints. The welded joint can be described as unsatisfactory.

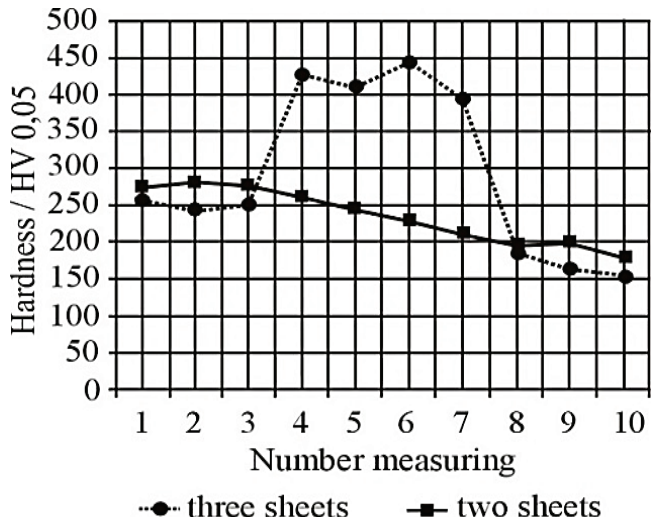

Figure 4 Microhardness values of welded joints using identical electrodes
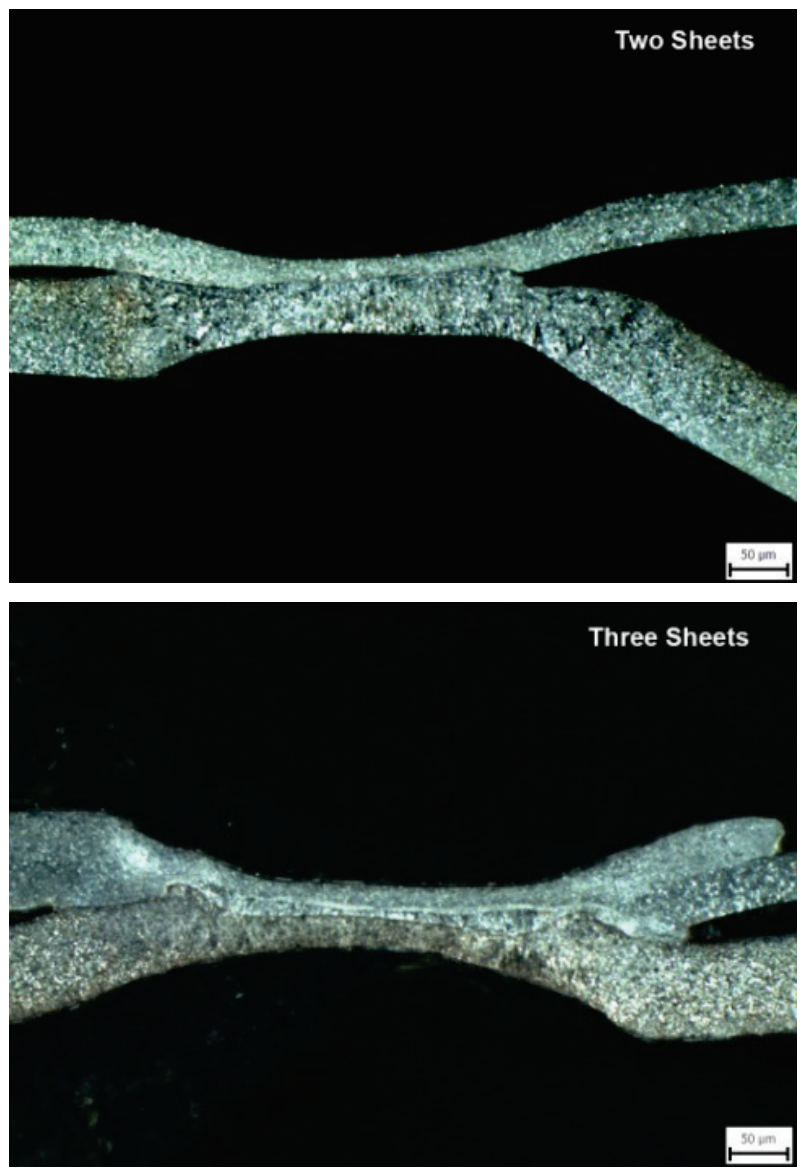

Figure 5 Macrostructure of spot welded joints - two and three sheets

The shape and geometry, along with the sticking of the zinc on the electrode surface, have an impact on other technological parameters. Weld metal porosity could create a problem with the electrodes which are welded 
through the plate's thickness. Another problem is excessively opening the sheets during the welding process (see Fig. 5) that was caused by an improper alignment of the electrodes on both surfaces, which caused the premature welded joints.

For this reason, the weld joint geometry is not convenient and plate compression must be extended before the welding process, which ensures a tight connection of welded plates [4]. The new electrode's geometry and a new material are able to establish a satisfactory connection where the molten zinc is squeezed out by the upper electrode radius. The bevels on both sides of the electrodes and a modified shape will allow better access to the welded joint (see Fig. 6).
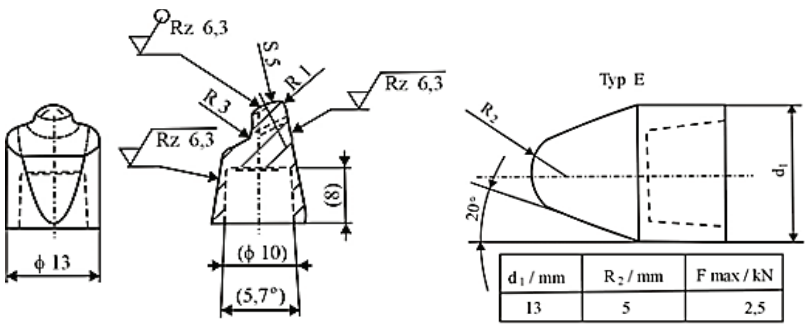

Figure 6 New geometry for the lower and upper electrodes

The material for the manufacturing of an electrode with a new geometry (see Fig. 6) was chosen according to the recommendations of the manufacturing company AEG. The recommended WIRBALIT B is the lower replaceable electrode, and WIRBALIT HF was used as the upper electrode for the heterogeneous welded joints [5]. Chemical composition of both materials is shown in table 4,5 .

Table 4 Chemical composition - WIRBALIT HF material [5]

\begin{tabular}{|c|c|c|c|c|}
\hline Chemical elements & $\mathrm{Cr}$ & $\mathrm{Zr}$ & $\mathrm{Cu}$ & other \\
\hline Content (\%) & 0,65 & 0,08 & residual & max. 0,2 \\
\hline
\end{tabular}

Table 5 Chemical composition - WIRBALIT B material [5]

\begin{tabular}{|c|c|c|c|c|c|}
\hline Chemical elements & $\mathrm{Co}$ & $\mathrm{Be}$ & $\mathrm{Cu}$ & $\mathrm{Ni}+\mathrm{Fe}$ & other \\
\hline Content $(\%)$ & 2,2 & 0,55 & residual & max. 0,5 & max. 0,5 \\
\hline
\end{tabular}

The welding parameter has been adjusted for different electrode materials and their geometry. The welding electrodes showed a damaged shape after two hours of operation and we can state that the lifetime period is identical with the original electrodes.

The welded joints (see Fig. 7) performed after electrode modification, and the welding parameters showed a satisfactory geometry in both cases. The microhardness for two and three sheets was another monitored parameter, see Fig. 8. The welded joints for two and three sheets showed the same trend of the increase and decrease of microhardness values. The maximal measured microhardness value for the weld joint was $420 \mathrm{HV} 0.05$.

Based on the unsatisfactory welded joints we performed an overall adjustment of the welding equipment. It has been changed of both forms of removable electrodes with a new geometry that fulfills its function as with poor access and poor in the initial material. Thanks to this, we achieved stability in the welding processes. The previous welding conditions had inappropriately selected the geometry and material of the welding electrodes, which caused an excessive adhesion of the zinc layer on the electrode's surface. This led to increasing the electrode's wear; the welded joints showed the creation of diffusion joints. The geometry of two interchangeable electrodes was selected from WIRBALIT HF material (the upper electrode) and WIRBALIT B (the lower electrode). Radius geometry ensures better zinc removal from a joint and does not cause excessive wear.
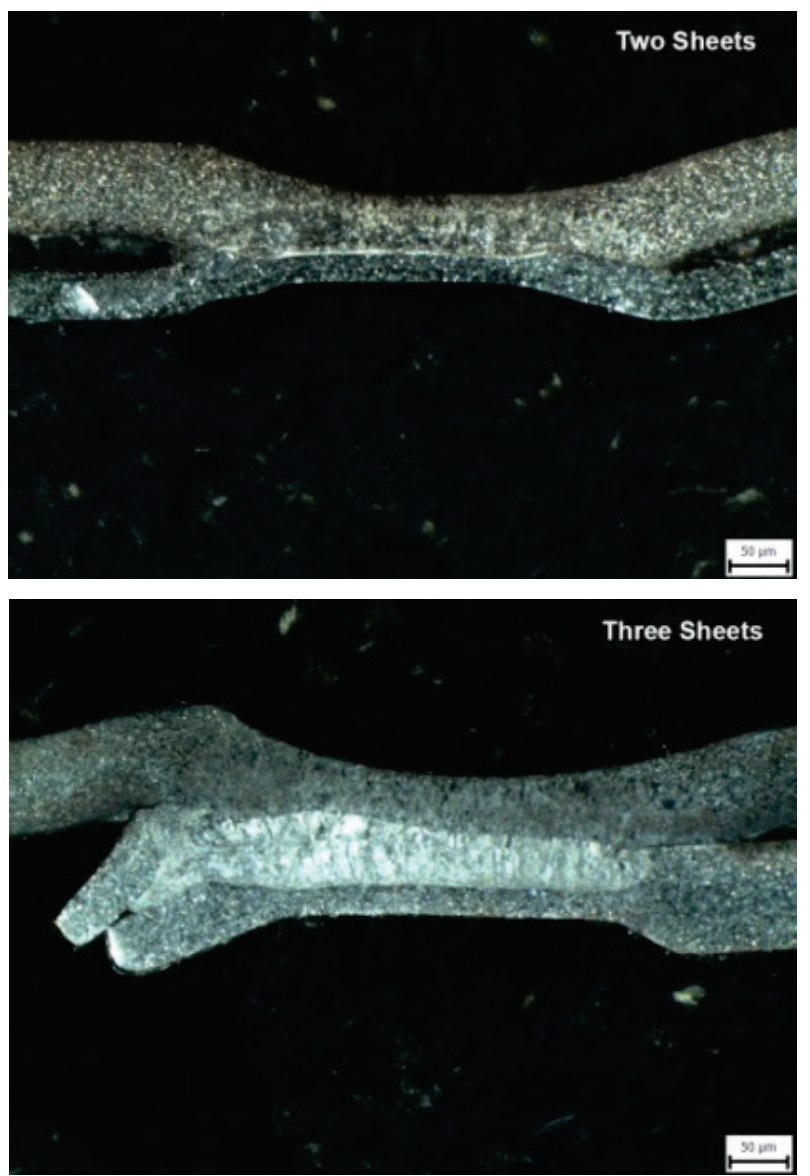

Figure 7 Macrostructure of spot welded joints for a new geometry

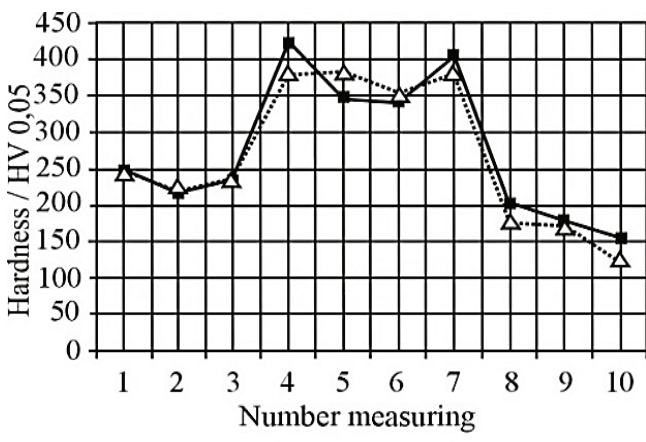

$\rightarrow-$ two sheets $\quad-\Delta \cdot$ three sheets

Figure 8 Microhardness values of welded joints using electrodes with a new geometry

\section{CONCLUSIONS}

Resistance spot welding is still achieved using pressure and heat and it is mainly used in industrial engineering. Therefore, the quality of welded joints is one of the most important requirements which these welded joints must meet. Many different factors that can be summarized as follows influence the topic of spot welded joints: 
- The base material and the number of sheets for joints have a great impact on the quality of the spot welded joint. In the present case, we tested a galvanized steel sheet and austenitic sheet: two sheets. The second variant is one galvanized and two austenitic sheets: three sheets. As one variable can be marked as welded joints from two and three sheets, the second variable can be marked as welded joints from the heterogeneous electric resistance welding of austenitic and galvanized steel sheets.

- The problematic area is the protective zinc layer on the sheet surface, especially its thickness that had a variable resistance ratio at a large number of spot welded joints. It is also necessary to push the molten zinc from the gap between the sheets in place of the created welded lens. In our case, we optimized the electrode geometry on the side of the galvanized steel sheet.

- The process of electric resistance welding is composed of many steps and parameter changes at short intervals. The parameters have been optimized and specific welded joints were tested on two and three sheets.

- The heterogeneous welded joint creates a problem from a material perspective. The mixing of the different base materials in the welding lens brings about a brittle fracture in the welded structure. Based on these results, we can say that the microhardness with a maximal value of $420 \mathrm{HV} 0.05$ is a satisfactory result.

\section{REFERENCES}

[1] Havránková, Z. (2007). A hypertext Přiručka žárového zinkování. Ostrava. http://www.zinkoza.sk/prirucka ziaroveho_zinkovania.pdf (22.09.2014)

[2] Euro Inox. (2002). A hypertext. Properties of Stainless Steels Euro Inox. http://www.worldstainless.org/Files/issf/non-imagefiles/PDF/Euro_Inox/BrochureWeldability_CZ.pdf (12.10.2014)

[3] DIN EN 10346:2009. Kontinuierlich schmelztauchveredelte Flacherzeugnisse aus Stahl - Technische Lieferbedingungen.

[4] Blaščík, F., Pilárik, S., Žitňanský, M., \& Polák, K. (1988). Technológia tvárnenia, zlievárenstva a zvárania. Alfa Praha, pp. 832.

[5] AEG Schweiss-technik., Mülheim an der Ruhr. 2014. A hypertext Recommendations on use. Available from: http://svsschweisstechnik.de (08.10.2014)

[6] Opderbecke, T. \& Fortain, J. M. (2011). New Solution ThinSheet Welding on Galvanized Sheet Metal in Automobile Construction by Arc Weld-Brazing and Welding. Air Liquide Company Documents.

[7] Nielsen, C. V., Friis, K. S., W. Zhang, W., \& Bay, N. (2011). Three-Sheet Spot Welding of Advanced High-Strength Steels. Welding Research, 90, 32-40. http://www.aws.org/wj/ supplement/wj201102_s32.pdf

[8] Krejčí, L., Hlavatý, I., \& Ševčíková, X. (2013). Transition zones study of the heterogenous welded joints. Metal $2013-$ The $22^{\text {nd }}$ International Conference on Metallurgy and Materials May 15 - 17, Brno, Czech Republic, 785-789.

[9] Harlin, N., Jones, T. B., \& Parker, J. D. (2003). Weld Growth Mechanism of Resistance Spot Welds in Zinc Coated Steel. Journal of Material Processing Technology, 143-144, 448-453. https://doi.org/10.1016/S0924-0136(03)00447-3
[10] Wong, Y. R. \& Pang, X. A. (2014). New Characterization Approach of Weld Nugget Growth by Real-Time Input Electrical Impedance. Engineering, 6, 516-525. https://doi.org/10.4236/eng.2014.69054

\section{Contact information:}

Ivo HLAVATÝ, Assoc. Prof., PhD, MSc

VŠB-Technical University of Ostrava,

Faculty of Mechanical Engineering,

17. listopadu 15, 708 33, Ostrava, Czech Republic

E-mail: ivo.hlavaty@vsb.cz

\section{Petra HÁJKOVÁ, MSc}

VŠB-Technical University of Ostrava,

Faculty of Mechanical Engineering,

Department of Mechanical Technology,

17. listopadu 15, 708 33, Ostrava, Czech Republic

E-mail: petra.hajkova.st@vsb.cz

Lucie KREJČí, PhD, MSc

VŠB-Technical University of Ostrava,

Faculty of Mechanical Engineering,

Department of Mechanical Technology,

17. listopadu 15, 708 33, Ostrava, Czech Republic

E-mail: lucie.krejci@vsb.cz

Robert ČEP, Prof., PhD, MSc

VŠB-Technical University of Ostrava

Faculty of Mechanical Engineering,

Department of Machining, Assembly and Engineering Metrology,

17. listopadu 15, 708 33, Ostrava, Czech Republic

E-mail: robert.cep@vsb.cz 